\title{
Potential Of Microalgae Chlorella vulgaris As Bioremediation Agents of Heavy Metal Pb ( Lead ) On Culture Media
}

\author{
Endah Rita Sulistya Dewi ${ }^{1^{*}}$, Riza Nuravivah $^{2}$ \\ ${ }^{1,2}$ Department of Mathematics, Sciences and Information Technology, PGRI Semarang University, Indonesia
}

\begin{abstract}
The purpose of this study to determine the ability of Chlorella vulgaris in absorbing $\mathrm{Pb}$ (lead) and the effect of the variation of $\mathrm{Pb}$ metal concentration on the growth of Chlorella vulgaris. This study using an experimental study with complete random design with 4 treatments, namely control (without the addition of metal), $\mathrm{Pb} 1$ (addition of metal $1 \mathrm{mg} / \mathrm{l}), \mathrm{Pb} 3$ ( $3 \mathrm{mg} / \mathrm{l})$ and $\mathrm{Pb} 5(5 \mathrm{mg} / \mathrm{l})$, respectively 3 replications. Exposure $\mathrm{Pb}$ ion in Chlorella vulgaris for 7 days. Analysis of the metal content of $\mathrm{Pb}$ concentration performed on culture media after exposure it at 3 hours after dispersion Chlorella vulgaris and on day 7 of culture using the AAS method. Do also counting the growth of cells each day. The results of the analysis of the average metal content of $\mathrm{Pb}$ in the culture medium at the end of the study was the control (0.1980), $\mathrm{Pb} 1$ (0.1453), $\mathrm{Pb} 3$ (0.4144) and $\mathrm{Pb} 5$ (0.5305). While the average growth of Chlorella vulgaris at the end of the study were control $\left(630.1116 \times 10^{4}\right), \mathrm{Pb} 1\left(829.0012 \times 10^{4}\right), \mathrm{Pb} 3\left(1069.9446 \times 10^{4}\right)$ and $\mathrm{Pb} 5\left(808.94450 \times 10^{4}\right)$. The results of the analysis of the content of $\mathrm{Pb}$ in the $\mathrm{F}$ test shown that the difference in concentration of water $\mathrm{Pb}$ given real influence on the ability of Chlorella vulgaris in absorbing $\mathrm{Pb}$ and growth. The conclusion of this study was Chlorella vulgaris has the ability to absorb metals in the waters, and the provision of various concentrations of $\mathrm{Pb}$ can affect the growth of Chlorella vulgaris.
\end{abstract}

\section{Introduction}

Control of the environment from pollution by industrial waste is one of the issues that need to be addressed, because it is potentially causing changes in water quality due to the influx of waste from these activities, particularly industrial waste containing heavy metals, which will lead to increasing pollutants carried by streams towards the estuary and will accumulate in the ocean.

These problems can affect the marine life that is therein to impact the lives of human dependence on marine environment is very large. One of the sewage treatment process to reduce pollution by heavy metals problem is to bioremediation, which is the process of converting waste contamination in an attempt to repair the quality of the environment by utilizing living things. Living creature that has great potential as a bioremediation agent is microalgae. Biological wastewater treatment to reduce heavy metals from polluted water into an alternative technology that has the potential to be developed. One of them utilizing ion exchange capacity and absorption ability of microorganisms to absorb heavy metals [3]; [10], Microalgae Chlorella vulgaris is an example that has the ability to absorb metal ions. Where the use of Chlorella vulgaris has not been maximized, only limited as a dietary supplement and ingredient manufacture of cosmetics.
Metallic lead most of its compounds are toxic. Lead and compounds can be in the water body naturally and as a result of human activity. Naturally, $\mathrm{Pb}$ can get into the water body through crystallization $\mathrm{Pb}$ in the air with the help of rain water. In addition, the process corrofication of mineral rocks due to the pounding waves and the wind. While $\mathrm{Pb}$ that goes into the water body as a result of the activities of human life there are various forms. Among them is the waste water (sewage) from $\mathrm{Pb}$ related industries, the waste water from the black tin ore and industrial waste discharge the battery. Wastes will fall in pathways such as the waters of the tributaries to then be carried over to the ocean. Generally the discharge line of industrial waste material which uses $\mathrm{Pb}$ will damage the system enters aquatic environments (make the river and polluted plot).

The purpose of this research activity, namely: Knowing decreased levels of $\mathrm{Pb}$ (lead) to the culture medium Chlorella vulgaris, knowing the effect of various concentrations of $\mathrm{Pb}$ (lead) on the growth of Chlorella vulgaris, knowing the results of research on concentration reduction of $\mathrm{Pb}$ (lead) and the growth of Chlorella vulgaris in the culture medium

\section{Research Methods}

Obtained from microalgae Chlorella vulgaris BBPBAP Jepara, and cultured in the laboratory of natural feed BBPBAP Jepara. For the analysis of metal test Lead $(\mathrm{Pb})$ is performed at the Laboratory of Chemical UNDIP 
Semarang. This research method using the experimental method completely randomized design (CRD) with 4 treatments three replications.

This research is Chlorella vulgaris cultured 7 days old alone for 7 days, the object of research is seawater samples by administering varying concentrations of $\mathrm{Pb}$.

Tools and materials used are 12 glass jars volume of 3 litre, rack culture, haemocytometer, microscopes, $\mathrm{pH}$ sticks, aerators, hose aeration, straws, measuring cup, beaker glass, refractometer, fluorescent lights long, pipettes, micro pipettes, filter paper, mineral water bottles, erlenmeyer, stove, Chlorella vulgaris, sea water (as an example), fertilizer walne, vitamin B12, heavy metals $\mathrm{Pb}\left(\mathrm{NO}_{3}\right)_{2}, \mathrm{NaOH}, \mathrm{HCl}, 70 \%$ solvent, soap and distilled water.

Working procedures implementing this study begins with the sterilization of tools that will be used. The sea water is also sterilized by boiling until boiling and let cool then filtered using filter paper. To get the salinity of sea water, in this study using a salinity of $25 \%$, using a dilution formula as follows:

$\mathrm{VI} \times \mathrm{S} 1=\mathrm{V} 2 \times \mathrm{S} 2$

Information:

$\mathrm{V} 1=$ Volume of sea water is sought $(\mathrm{L})$

$\mathrm{S} 1=$ initial seawater salinity $(\%)$

$\mathrm{V} 2$ = volume of sea water necessary to the culture medium (L)

$\mathrm{S} 2=$ desired Salinity $(\%)$

[2]

Mixing of compounds $\mathrm{Pb}(\mathrm{NO} 3) 2$ on each vessel with four variations of concentrations $(0 \mathrm{mg} / 1,1 \mathrm{mg} / 1,3 \mathrm{mg}$ $/ 1$, and $5 \mathrm{mg} / 1)$. Chlorella vulgaris cell density used is \pm $1 \mathrm{x} 106$ cells / ml. The calculation of the number of cells using haemocytometer using the following formula:

The number of cells $/ \mathrm{ml}=\frac{\text { (total number of cellsin } 3-4 \text { blocks) }}{\text { (number ofblocks) }} \times 10,000 \times \mathrm{P}$ [6].

To get cell density of $\pm 1 \times 106$ cells / ml, then the dilution calculation using the formula as follows:

$\mathrm{V} 1 \times \mathrm{V} 2 \times \mathrm{N} 1=\mathrm{N} 2$

Information:

$\mathrm{V} 1=$ Volume of Chlorella vulgaris necessary for culture

$\mathrm{N} 1=$ density cell culture seedlings on stock

$\mathrm{V} 2=$ volume of seawater used as a culture medium

$\mathrm{N} 2$ = density desired cells for culture

(6).

The calculation of the rate of growth of Chlorella vulgaris done every day, using the formula:

The number of cells $/ \mathrm{ml}=\frac{\text { (total number of cellsin } 3-4 \text { blocks) }}{\text { (number of blocks) }} \times 10,000 \times \mathrm{P}$ Information:

$\mathrm{P}=$ Dilution (to do if experiencing difficulty in the calculation for the number of cells is too much). [6].

Chlorella vulgaris in cultivation for 7 days in media $\mathrm{Pb}$ with walne as fertilizer nutrients. Control variables such as temperature, salinity and $\mathrm{pH}$ is controlled every day. Chlorella vulgaris cultures was centrifued to separate the sea water as a cell culture medium with Chlorella vulgaris (as solids). $\mathrm{Pb}$ concentration measured using AAS method after 3 hours after the stocking of seeds of Chlorella vulgaris and day 7 and measure the growth of Chlorella vulgaris every day using a haemocytometer.

\section{Results and Discussion}

\subsection{A decrease in concentration of metals $\mathrm{Pb}$ (Lead) by Chlorella vulgaris}

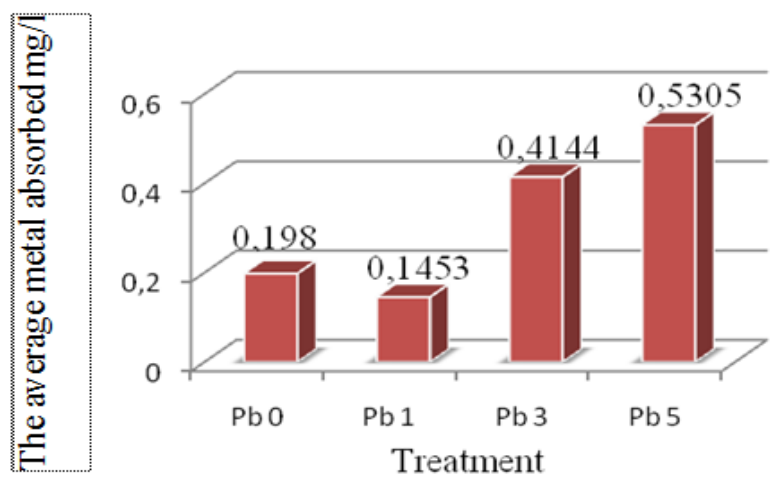

Fig. 1. The decline in the average concentration of $\mathrm{Pb}$

Information:

$\mathrm{Pb} 0=$ Media Chlorella vulgaris without the addition of $\mathrm{Pb}$

$\mathrm{Pb} 1=$ Media Chlorella vulgaris with the addition of $\mathrm{Pb}$ $1 \mathrm{mg} / 1$

$\mathrm{Pb} 3$ = Media Chlorella vulgaris with the addition of $\mathrm{Pb}$ $3 \mathrm{mg} / 1$

$\mathrm{Pb} 5=$ Media Chlorella vulgaris with the addition of $\mathrm{Pb}$ $5 \mathrm{mg} / 1$

From the diagram of Figure 1 shows that the highest concentrations of $\mathrm{Pb}$ absorbed contained on the treatment $\mathrm{Pb} 5(\mathrm{~Pb} 5=0.5305)$, this means that the more the concentration of each metal were absorbed by the Chlorella vulgaris. This is in accordance with the results of research by [3], that an increase in metal biosorption ability is directly proportional to the increase in concentration. This absorption occurs because of the $\mathrm{OH}$ groups in cellulose Chlorella vulgaris which is polar.

There are many things that cause absorption mechanism of $\mathrm{Pb}$ (lead) by Chlorella vulgaris occurred in the treatment $\mathrm{Pb} 1, \mathrm{~Pb} 3$ and $\mathrm{Pb} 5$, such as the cellulose in the cell walls of Chlorella vulgaris. Chlorella vulgaris cell wall structure of cellulose. In the chemical structure of cellulose has an $\mathrm{OH}$ group. Cellulose is potentially large enough to be used as a metal ion catcher because of the $\mathrm{OH}$ groups are bound to interact with the adsorbate, adsorbate in this study is $\mathrm{Pb}$. $\mathrm{OH}$ group causes the polar nature of the adsorbent, the adsorbent in this case is the cellulose contained in the cell wall of Chlorella vulgaris. Thus the $\mathrm{OH}$ groups in cellulose can absorb more strongly polar substances of the substance less polar. The 
presence of the $\mathrm{OH}$ group causes metal ions $\mathrm{Pb}$ absorption mechanism in the cell walls of Chlorella vulgaris. Interactions between the cellulose in the cell walls of Chlorella vulgaris with $\mathrm{Pb}$ ion is an extracellular detoxification mechanism or mechanisms of tolerance. Detoxification is the process of conversion of heavy metals into non-toxic form.

Reduced levels of $\mathrm{Pb}$ in the culture medium Chlorella vulgaris it can also takes place through the formation of the metal-binding protein found in microalgae, among others metalotionein and fitokelatin. According [11], Chlorella sp, cells of phytoplankton metabolic processes can synthesize metal chelating protein fitokelatin to respond to the negative effects of heavy metals. The protein can bind to heavy metals because it has sulfhydryl groups (-SH) and will accumulate in the vacuole, through enzymatic processes. According [13], which contains sulfhydryl groups can easily bind to metal ions that enter the body. Fitokelatin will form complexes with heavy metal and serves as detoksifikan [4]. Fitokelatin synthesized from a tripeptide derivative (glutathione), if the environment is polluted by $\mathrm{Pb}$, then it will form fitokelatin glutathione. Fitokelatin will further establish fitokelatin- $\mathrm{Pb}$ which will be forwarded to the vacuole [11]. Microalgae generally have a protective mechanism against toxic metals to keep to his own life. This mechanism involves the formation of metal complexes with proteins in the cell membrane so that the metal can accumulate in the cell without interfering with growth. If so high metal concentrations, accumulation may inhibit cell growth because the organism protection system is no longer able to offset the effects of the toxic metal, other than that it is also related to the size of the cell Chlorella vulgaris [12]; [7].

Associated with the role, $\mathrm{Pb}$ is in the cell work in assisting the action of the enzyme for its metabolism. According [13], in carrying out its duties enzymes often require metal or a vitamin or a combination of both as a cofactor and activator. Generally, the active center of the enzyme is a group of metal ions. However, enzymes that have metal ions as active centers tend to be volatile. This is due to metal ions contained in a group of enzymes can often be replaced by other metals that come inside. The circumstances shift metal ions contained in a group of enzymes will be very easy to happen when there is deficiency. $\mathrm{Zn}$ and Fe deficiency often causes influx of $\mathrm{Pb}$ to replace the function of the metal ions from the group of enzymes. It turned out that the metal ions are signed to replace metal ions that should play a role (in this case $\mathrm{Pb}$ ), has made the cause of the obstruction of the work ability of the related enzyme. $\mathrm{Pb}$ ion thus herein referred to as inhibitors (barrier) if the concentration exceeds the threshold. If there is one type of enzyme that disturbed her, certainly can affect the work of other enzymes. If this is allowed to continuously, it will interfere with the metabolism of the cell body. Simply put, the reaction can be illustrated as follows:

Enzyme + Substrate $\longrightarrow$ enzyme (enzyme active), in the presence of metal ions into the reaction,

Enzymes + Metal $\longrightarrow$ enzyme (enzyme active).
However, if the optimal absorption of $\mathrm{Pb}$ concentrations found in treatment $\mathrm{Pb} 5$ associated with optimal growth of Chlorella vulgaris cells in treatment $\mathrm{Pb} 3$. This means the treatment $\mathrm{Pb} 5(\mathrm{~Pb} 5 \mathrm{mg} / 1)$, the more metals are absorbed would interfere with cell growth of Chlorella vulgaris. This is in accordance with the previous explanation, that could be a barrier $\mathrm{Pb}$ action of an enzyme that would result in disruption of cell metabolism. While on treatment $\mathrm{Pb} 3$ optimal cell growth occurred Chlorella vulgaris, meaning the concentration of $\mathrm{Pb} 3 \mathrm{mg} / \mathrm{l}$ can still be tolerated by Chlorella vulgaris. This is consistent with the statement of [8]; [1], that the metal disc at the microalgae will become an obstacle in the metabolism of cells at high concentrations, but will be useful in the process of metabolism in moderate concentrations.

In addition, the mechanism of absorption of $\mathrm{Pb}$ by Chlorella vulgaris can also be due to the alginate to the wall sel Chlorella vulgaris. According to the research [3[, the alginate is a polysaccharide constituent contained in Chlorella vulgaris cell wall can bind with metals $\mathrm{Pb}$, so the presence of metal ions $\mathrm{Pb}$ in the water levels are less toxic to the organism are others nearby. The mechanism of ionic bonds between the alginate with $\mathrm{Pb}$ are as follows:

$3 \mathrm{NaAlg}+\mathrm{PB} 3+\mathrm{Pb}(\mathrm{Alg})_{3}+3 \mathrm{NA}$.

Based on the chemical reaction, $\mathrm{Pb}$ ion binds to alginate so that $\mathrm{Pb}$ does not pollute the water because it forms ions are already bonded.

\subsection{The growth of Chlorella vulgaris cells in Media Metals $\mathrm{Pb}$ (Lead)}

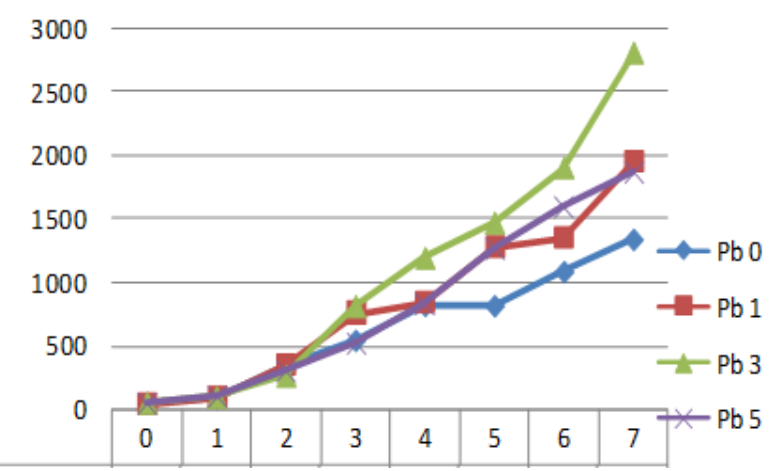

Fig. 2. Growth of Chlorella vulgaris cells for 7 days

Information:

$\mathrm{Pb} 0=$ Media Chlorella vulgaris without the addition of $\mathrm{Pb}$

$\mathrm{Pb} 1=$ Media Chlorella vulgaris with the addition of $\mathrm{Pb}$ $1 \mathrm{mg} / 1$

$\mathrm{Pb} 3=$ Media Chlorella vulgaris with the addition of $\mathrm{Pb}$ $3 \mathrm{mg} / 1$

$\mathrm{Pb} 5=$ Media Chlorella vulgaris with the addition of $\mathrm{Pb}$ $5 \mathrm{mg} / 1$

Based on the growth data, all treatments are in a phase of adaptation in the day during a 3 hour stocking of seedlings Chlorella vulgaris, and day 1 to day 7 an exponential phase. Growth is highest in the treatment of 
$\mathrm{Pb} \mathrm{3}$, the lowest in the control treatment was followed treatment $\mathrm{Pb}$ 5. This means that at certain concentrations of $\mathrm{Pb}$ is required, but at high concentrations it will hamper growth. According to [7], microalgae generally have a protective mechanism against toxic metals to keep to his own life. If so high metal concentrations, accumulation may inhibit cell growth because the organism protection system is no longer able to offset the effects of toxic metals. Decreasing the concentration of $\mathrm{Pb}$ is also affected due to nutritional factors and increase the number of cells in the culture medium.

Another factor influencing the growth of Chlorella vulgaris cells is salinity. Initial salinity used in this study was $25 \%$ and continues to increase each day until it reaches the highest salinity on the 7 th day that is $50 \%$. The increase in salinity during the culture can occur due to the metabolism of the cell or precipitation of salts and nutrients in the medium. The salt concentration in the medium increases due to the evaporation of sea water used as a culture medium for the heat lamp TL which is close to the jar for culture. This is evidenced by the discovery of salt deposits on the surface of the white wall of the jar mouth and culture during the study. According [5] ; [9], environmental influences such as temperature, salinity, $\mathrm{pH}$ and dissolved oxygen levels in the water can also affect the toxicity of metals in water to living things in it. With the decline in value of salinity will increase the toxicity of the metal.

\section{Conclusion and Recommendations}

1. The microalgae Chlorella vulgaris giving effect to the decrease of various concentrations of $\mathrm{Pb}$ in the culture medium, with the highest absorption is $\mathrm{Pb}$ metal on the treatment $\mathrm{Pb} 5$, and absorption of $\mathrm{Pb}$ smallest $\mathrm{Pb} 1$ treatment.

2. Related to the provision of various concentrations of $\mathrm{Pb}$ influence on the growth of Chlorella vulgaris. At concentrations of $\mathrm{Pb} 1 \mathrm{mg} / 1$ and $3 \mathrm{mg} / 1$ can be tolerated by the cell Chlorella vulgaris, and optimal growth contained in the treatment $\mathrm{Pb3}$, while at a concentration of $5 \mathrm{mg} / 1$ can no longer be tolerated by cells of Chlorella vulgaris, it is characterized by decreasing the number of cells Chlorella vulgaris in the culture medium.

\section{References:}

1. Andersen. Algal Culturing Techniques. Oxford: Elsevier Academic Press, (2012)

2. Arrokhman. Survival Rate Ikan Bawal Bintang (Trachinotus blochii) dalam Media Pemeliharaan Menggunakan Rekayasa Salinitas Jurnal Sains Dan Seni Its Vol. 1, No. 1, (Sept. 2012) ISSN: $2301-$ 928x, (2012)

3. Aunurohim. Jurnal Sains dan Seni Pomits Vol. 3, No. 1, 2337-3520, (2014)

4. Cobbet, CS. Phytocelatin Biosynthetis and Function in Heavy Metal Detoxification. Curr. Opin. Plant. Biology.3, (2000)

5. Darmono. Lingkungan Hidup dan Pencemaran Hubungannya dengan Toksikologi Senyawa Logam. Jakarta: UI Press, (2001)

6. Fardias, S. Teknik Dan Prosedur Dasar Laboratorium. Jakarta: PT Gramedia, (1985)

7. Hala,Y., Paulina Taba, and Febrianti Rut Langan. Potensi Mikroalga Laut Nannochloropsis salina Sebagai Biosorben $\mathrm{Ni}^{2+}, \mathrm{Cu}^{2+}$, dan $\mathrm{Zn}^{2+}$ dalam Medium Conwy Terkontaminasi Campuran Tiga Logam Chem. Prog. 5 (2),86, (2012)

8. Held, Paul and Keri Raymond. Determination of Algal Cell Lipids Using Nile Red Using Micro Plates to Monitor Neutral Lipids in Chlorella vulgaris AN071211_08, Rev. 07/12/11. bioTek Application Note, (2011)

9. Hermanto, Perancangan Bioreaktor Untuk Pembudidayaan Mikroalga. Jurnal Teknologi Pertanian Vol. 12 No. 3 (Desember 2011) 153-162, (2011)

10. Hlihor, RM., Diaconu, M. Chelaru, C. Sandu, I., Tavares, T. and Gavrilescu. J. Environ. Res., 7(3), 581-594, ISSN: 1735-6865, (2013)

11. Lehniger, A L., Nelson D.L., and Cox M.M. Principles Of Biochemistry, Second Edition. New York: Worth Publishers (1993)

12. Manuela D.Machado, Eduardo V. Soares, Helena. MVM. Soares. Journal of Hazardous Materials. 180: 347-353, (2010)

13. Palar, Heryando. Pencemaran dan Toksikologi Logam Berat. Jakarta: Rineka Cipta, (2008) 